\title{
HEARING PROCEDURES OF THE OFFICE OF THE COMPTROLLER OF THE CURRENCY
}

\author{
ROBERT BLOOM*
}

Elsewhere in this symposium, Professor Kenneth Culp Davis of the University of Chicago takes exception to an allegedly excessive level of confidentiality accorded material developed in handling bank charter and branch applications, and to a related allegedly unfair decision-making process, in the Office of the Comptroller of the Currency and other banking agencies. ${ }^{1}$

We in the Comptroller's Office regret the fact that some of our procedures have met with the disapproval of so eminent an authority on administrative law, but at the same time we are grateful for the time and attention Professor Davis has given to the Office. Whenever possible, we have endeavored to follow his advice. On some matters, however, we feel that we are in a better position than he to assess the degree of formality of procedure that will best serve the banking industry and the public generally.

\section{I}

\section{Recent Departures from Traditional Practices}

When former Comptroller James J. Saxon took office in November I96r, he found in existence methods of handling applications for new banks, branches, and mergers that had not been changed for decades. Almost every piece of paper pertaining to an application was considered secret, and virtually no public announcements of any kind emanated from the Office. In the preceding ninety-eight-year history of the Office, there had never been a public hearing or a written opinion published on an application. Anything that smacked of controversy was considered bad for the banking "image."

In fairness to all of Mr. Saxon's distinguished predecessors in office, we hasten to state that these methods are the traditionally accepted ones for a bank supervisory agency. They obviously could not have survived as long as they did without the approval of the industry affected, ${ }^{2}$ of the courts, ${ }^{3}$ and of Congress. ${ }^{4}$ Indeed, there are

- Chief Counsel to the Comptroller of the Currency.

${ }^{2}$ Davis, Administrative Procedure in the Regulation of Banking, in this symposium, p. 7 13.

${ }^{2}$ Attorney General's Comam. on Administrative Procedure, Administrative Procedure in Governnient Agencies, S. Doc. No. 8, 77th Cong., Ist Sess. I42-43 (I94I).

${ }^{8}$ Bridgeport Fed. Sav. \& Loan Ass'n v. Federal Home Loan Bank Bd., 307 F.2d 580 (3d Cir. I962), cert. denied, 37I U.S. 950 ( 1963 ); Northwest Bancorporation v. Board of Governors, 303 F.2d 832, 842-44 (8th Cir. 1962); First Nat'l Bank of McKeesport v. First Federal Sav. \& Loan Ass'n, 225 F.2d 33 (D.C. Cir. 1955). For cases decided since the beginning of Mr. Saxon's administration, see notes I2, 15-18, $21-23$ infra.

'Congressional approval of these practices would seem to be implied by inaction over a long period and to be clearly expressed in the recent amendment to section 3 of the Administrative Procedure Act. 
obvious and valid reasons for a more confidential treatment of banking matters than is afforded other industries. The files of banks and bank supervisors contain much information concerning the financial, business, and private affairs of the banks, their personnel, and their customers. The persons concerned are entitled to have such information kept private in the absence of the most compelling circumstances. This right has been recognized by legislatures in statutes making it a criminal offense for such matters to be disclosed" and most recently in the so-called "Freedom of Information" Act. ${ }^{6}$

These time-honored procedures, to which we shall refer hereafter as the "traditional" approach, are still followed today by the other two federal banking agencies and by the great majority of state banking agencies in the handling of applications for approval of new banks or branches.

Intertwined with the traditional approach in procedure when Mr. Saxon took office was an equally "close-to-the-vest" approach to substantive policy on branch and charter applications. Large cities had gone for decades without the entry of a single new bank, although population, aggregate income, and business units had increased markedly and many financially and professionally qualified groups had expressed interest in organizing new banks. An equally restrictive policy had been followed with respect to branches, sometimes as a result of unwritten understandings with state supervisors.

Soon after Mr. Saxon assumed his position, he determined to "open up" the Comptroller's Office, as to both substance and procedure. The first public hearing in the history of the Office was held in December I96I in connection with the application of First National City Bank of New York to acquire the National Bank of Westchester. That case also provided the occasion for a twenty-four page opinion, the first such published by the Office. Since that time there have been several widely publicized hearings held by the Office and many more which were public in the sense that anyone could attend but which in fact were attended only by the applicants and protestants.

In the past several years we have constantly strived to improve and open up our

5 U.S.C.A. § 1002 (Supp. 1966) (effective July 4, I967), amending 5 U.S.C.A. §552 (Special Pamphlet 1966). The purpose of the amendment is "to provide a true Federal public records statute by requiring the availability, to any member of the public, of all the executive branch records described in its requirements." H.R. REP. No. 1497, 89th Cong., 2d Sess. I (1966). Yet $\$$ I002(e) (8) exempts from the requirements of the section "matters that are .. . contained in or related to examination, operating, or condition reports prepared by, on behalf of, or for the use of any agency responsible for the regulation or supervision of financial institutions." In justifying this exception to the general provisions of the statute, the House Government Operations Committee stated, "This exemption is designed to insure the security and integrity of financial institutions, for the sensitive details collected by Govern. ment agencies which regulate these institutions could, if indiscriminately disclosed, cause great harm." Id. at II. This language appears to be an express approval of the Comptroller's prior practice of withholding such information "in order to protect the national banking system" in a number of specificd respects. I2 C.F.R. \$4.13(b) (Supp. I966).

${ }^{5}$ See, e.g., 18 U.S.C. $\$$ Ig06 (1964).

${ }_{5}{ }_{5}$ U.S.C.A. $\$ 1002$ (Supp. I966) (effective July 4, I967). See note 4 supra. 
procedures to the maximum degree while at the same time recognizing the continuing merits of the more informal approach of the past. Among the changes of a procedual nature aimed at this goal that were made under Mr. Saxon's administration was the abrogation of all secret agreements between the Comptroller's Office and state supervisors concerning the disposition of applications for branches or new banks.

Mr. Saxon also introduced the requirement that a copy of each application for a new bank charter be published in a local newspaper within fifteen days after acceptance for filing by our Office, thereby improving the opportunity for interested parties to respond. And under Mr. Saxon's leadership the following procedural changes have been made in the handling of contested branch and new-bank applications:

(I) Since early Ig66, all written material submitted by either applicants or protestants has been made available for the inspection of all parties, with the exception of personal financial and biographical data which are solicited by and submitted in confidence to the Office.

(2) Since July I966, the report of investigation of the Comptroller's field examiners has been made available to applicants and protestants.

(3) When requested by any party, a public hearing is scheduled at the office of the Regional Administrator at the convenience of the parties. Applicants and protestants are notified of the time and place of such hearings and are permitted to send representatives or attorneys to it.

(4) Parties are permitted to question each other through the presiding officer or directly. Since there is some doubt as to the authority of the Office to require persons appearing before it to submit to cross-examination by persons other than representatives of the Office, cross-examination has been on a voluntary basis. But this appears to be of little practical importance since no witness has ever objected to cross-examination. The distinction may be important, however, in maintaining the character of hearings held by the Office as essentially investigative rather than adversary in nature.

(5) If requested and paid for by any party, a full verbatim transcript of the hearing is taken by a commercial reporting service. Copies of the transcripts are available to any party wishing to purchase the same.

(6) Following the hearing, and after he has had an opportunity to consider the entire record, the Comptroller communicates his decision by letter to the applicants and to others by publication in the Office's Summary of Activities. The Comptroller has recently started to write opinions in contested cases summarizing the factual and legal bases for his decision.

(7) If an appeal to a court is taken from the Comptroller's decision in a case in which judicial review is available, an administrative record is submitted to the court, which record normally contains the application and all supporting economic data submitted by the applicant, all material submitted by the protestants, the 
report of investigation by the Comptroller's staff, a verbatim transcript of any hearings held, and the Comptroller's written decision.

(8) The hearing conferences are normally held by a Deputy Comptroller or Regional Administrator and are in the nature of investigative proceedings rather than trials. As Professor Davis has stated, trial-type proceedings are ordinarily not desirable in connection with the determination of subjective issues such as the degree to which a new bank or branch will serve the public interest. ${ }^{7} \mathrm{~A}$ legislative-investigative type of hearing with each side presenting its arguments and data on the issues presented, both orally and in writing, is best designed to present the kind of record needed by both the Comptroller and a reviewing court.

The above changes have not as yet been formalized in a published regulation applicable nationally, since we are still frankly in a period of development and experimentation. The procedures are also involved in several court cases which have not been finally determined.

\section{II}

\section{Measuring the Comptrolier's Performance Against the Davis Standards}

Since the above-listed innovations constitute the bulk of the changes in the hearing procedures of the federal banking agencies during the past five (or ninety-five) years, we read Professor Davis's article with some surprise. In his widely known Administrative Law Treatise, Professor Davis had the following to say about the hearing procedures of the Comptroller's Office: ${ }^{8}$

\section{$\$$ 4.04. Supervision of Banking}

Probably the outstanding example in the federal government of regulation of an entire industry through methods of supervision, and almost entirely without formal adjudication, is the regulation of national banks. The regulation of banking may be more intensive than the regulation of any other industry, and it is the oldest system of economic regulation. The system may be one of the most successful, if not the most successful. The regulation extends to all major steps in the establishment and development of a national bank, including not only entry into the business, changes in status, consolidations, reorganizations, but also the most intensive supervision of operations through regular examination of banks.

The substantive systems of regulation by such nonbanking agencies as the ICC, FPC, and FCC are much the same as one portion of the system of regulation by the banking agencies, the portion having to do with the requirement of licenses and approvals. The major substantive difference in the systems of regulation is that the banking agencies have and the nonbanking agencies lack the power of close supervision of day to day operations.

The striking fact is that whereas the nonbanking agencies administer their systems of requiring licenses and approvals by conducting formal adjudications in most cases involving controversies, the banking agencies use methods of informal

\footnotetext{
${ }^{7}$ K. C. Davis, Administrative Law Treatise $\$ \$ 4.04,7.16$ (Supp. 1965).

${ }^{8}$ Id. $\$ 4.04$, at $247-48$.
} 
supervision, almost always without formal adjudication, even for the determination of controversies. The contrast is a striking one with respect to each parallel problem; for instance, the problem of the extent of community need is about the same whether the application is for establishment of a bank, a television station, or an airline, and yet the problem is handled in the banking field by the methods of the business man and in the other fields by the methods of the judge in his courtroom.

The above words of approval were written at a time before any of the procedural improvements listed above and hardly seem consonant with the severity of Professor Davis's current attack.

In view of the substantial procedural changes that have been made in the Comptroller's Office, most of the criticisms that form the basis of Professor Davis's article appear to have been met. His principal proposal, that competitors be given access to materials submitted in support of a contested application, has been generally in effect for about a year. While it is true that in past years the reports of national bank examiners who investigated applications were held in confidence in order to protect the independence of their judgment, this policy is no longer followed. These reports are now made available to protestants prior to the public hearing.

Similarly, the Comptroller now generally accompanies his decisions on contested applications with opinions that summarize the factors on which he relied in reaching his conclusion. The difficulty here, of course, as Professor Davis recognizes, is that many of the most crucial elements of any decision on a branch or new charter application are highly subjective in nature. An assessment of such factors as the caliber of the applicants' respective management, the degree of aggressiveness shown by existing institutions, and the potential competitive effect of the new facility does not lend itself to specific factual delineation in the detailed format customarily associated with findings of fact.

Nevertheless, the opinions now being rendered by the Comptroller do give a clear indication of the factors on which he principally relied in reaching his decision (the details of these are of course found in the public administrative file). While it would be unwise to attempt to set inflexible precedents in such an informally supervised and subjective area of regulation, these opinions should nevertheless serve as a guide for prospective applicants to the general outlines of the Comptroller's regulatory policies.

Mr. Saxon and previous Comptrollers have in fact made numerous "policy statements" with respect to the factors relevant to the granting of new charter and branch applications. ${ }^{9}$ As we have suggested above, the nature of these decisions renders it

'See, e.g., "What Kind of Banking Structure Do We Want?-The Role of Branch Banking" (remarks of James J. Saxon before the New York Financial Writers Ass'n, May 27, 1963), reprinted in Hearings Before the House Comm. on Banking and Currency on Conflict of Federal and State Banking Lawws, 88th Cong., Ist Sess. 37I-75 ( 1963 ); "Bank Expansion and Economic Growth: A New Perspective" (remarks of James J. Saxon to the National Credit Conference of the American Bankers Ass'n, Jan. 22, I963). 
not only unwise but virtually impossible to spell out these factors in great detail. No formulae based on bank-to-population ratios, comparative rate of sales tax growth, number of industries, or any of the innumerable other factors that might be considered in passing on such applications could or should be hardened into policy or precedent. Professor Davis's oft-expressed concern with preserving a fair degree of flexibility and informality in banking regulation would indicate that he would not dissent from this view.

\section{III}

Recent Litigation Concerning the Comptroller's Hearing Procedures

In 1963 , in testimony before the House Committee on Banking and Currency, Mr. Saxon testified that, contrary to the "traditional" Office attitude, he did not resent court challenges to his actions, whether based on substantive or procedural grounds. ${ }^{10}$ There have been a number of suits filed in which competitor banks have sought to impose full Administrative-Procedure-Act, trial-type hearings in the handling of branch and new-bank applications. We have resisted these efforts for two main reasons.

First, as even Professor Davis asserts, the trial-type hearing is an inefficient and clumsy way to gather the economic facts and opinions necessary to decide intelligently whether to permit the opening of a new bank or branch. This information is developed more completely and clearly by an appellate type of presentation. It is incongruous to ask witnesses to "swear" that they need a new bank in town or that the corner of First and Main would be a good place for a branch. The optimistic city booster or real estate developer should not be put to the oath as to the prospects of a town or shopping center.

Second, trial-type proceedings are inherently too expensive and slow, and too conducive to dilatory tactics on the part of protestants, to afford fairness to would-be bankers or to the industry. The economic value of keeping a competitor out of a choice suburban location for two or three years could well, in branch and charter cases, make it worthwhile for competitor institutions to demand formal hearings and court review, regardless of the merits of their position. ${ }^{11}$ The organizers of proposed new banks would be especially disadvantaged because of their meager resources in comparison with established banks.

To date every court that has passed on the question has held with the Comptroller that there is no constitutional or statutory requirement that he hold formal APA hearings. The most recent decision is that of the Court of Appeals for the Eighth Circuit in Webster Groves Trust Co. v. Saxon, ${ }^{12}$ a case involving an application for

\footnotetext{
${ }^{10}$ Hearings, supra note 9, at 395.

${ }^{12}$ Hearings on $S .166_{3}$ Before the Senate Comm. on Administrative Practice and Procedure, 88th Cong., 2d Sess. (1964).

${ }_{12} 370$ F.2d 381 (8th Cir. 2966$)$.
} 
a new bank charter. The court upheld the Comptroller's position and approved the traditional informal proceedings of the Office, saying this: ${ }^{13}$

The National Banking Act is the source of the Comptroller's powers and duties in the granting of a national bank charter. This Act sets forth no requirement of a formal hearing on an application for a charter. The legislative history of the Act clearly indicates that no formal hearing was intended by Congress. After enumerating the detail [sic] requirements, I2 U.S.C. $\$ 27$ authorizes the Comptroller to issue a certificate of authority:

"If, upon a careful examination of the facts so reported, and of any other facts which may come to the knowledge of the Comptroller, whether by means of a special commission appointed by him for the purpose of inquiring into the condition of such association, or otherwise, it appears that such association is lawfully entitled to commence the business of banking ***."

The Comptroller's practice for over one hundred years has been to proceed informally on these new bank applications. This practice has received the approval of the Attorney General's Committee on Administrative Procedure and has gone unchallenged in at least the appellate courts for the same period of time. ${ }^{14}$

The very nature of the decision required by the Comptroller indicates that a formal adversary type hearing would be of little benefit to him in the discharge of his discretionary powers. There is the further factor present that if bank applicants were subjected to severe public cross-examination, public presentation of unfavorable evidence, and were forced to disclose their future plans and programs to competitors, public confidence in the banking system could be adversely affected.

The same conclusion had previously been reached by district courts in Citizens National Bank of Maplewood v. Saxon, ${ }^{15}$ Citizens Bank of Hattiesburg v. Saxon, ${ }^{16}$ and Trust Co. of New Jersey v. Saxon. ${ }^{17}$

The Court of Appeals for the Fourth Circuit, in First National Bank of Smithfield v. Saxon, ${ }^{18}$ considered the question with reference to an application for a new branch of an existing bank. The majority, Judges Bryan and Boreman, held that neither statute nor the Constitution required any particular procedure on the part of the

\footnotetext{
${ }^{18}$ Id. at $384-85$.

12 [Footnote in original.] An excerpt from the Report of the Attorney General's Committee on Procedure, pp. 142-143, Sen. Doc. No. 8, 77th Cong., Ist Sess., is as follows:

"The Committee recognizes, however, that a major safeguard is careful and conscientious investigation, that in determining whether individuals are suited to engage in the banking business, or whether the community needs a bank, or whether a bank should be insured, and similar questions, a congeries of imponderables is involved, calling for almost intuitive special judgments so that hearings are not ordinarily useful, and that the banking business is a delicate one so that the advantages and importance of ready and frank information may outweigh the dangers of accepting confidential information. Accordingly, and in the absence of any substantial evidence that there has been an abuse of power, the Committee is not prepared to recommend that either hearings be held prior to denial or that in all cases the identity of the author of the adverse evidence be disclosed to the applicant."

18249 F. Supp. 557 (E.D. Mo. I966).

${ }^{10}$ Civil No. 1998 (S.D. Miss., Feb. I4, I966).

${ }^{17}$ Civil No. 532-63 (D.N.J., Sept. 9, 1963).

${ }^{18} 352$ F.2d 267 (4th $\mathrm{Cir}$. I965). The administrative proceedings involved in Smithfield were held in 1963 , prior to the institution of many of the innovations in procedure described in the text.
} 
Comptroller. But the court went on to hold that the administrative record before the court was inadequate to permit review on the record. The case was remanded to the district court with instructions to take evidence de novo on the issues of public convenience and need for the new branch. The court stated as follows: ${ }^{10}$

The Banking Act, I2 U.S.C. $\$ 36(c)$, in permitting bank branching "with the approval of the Comptroller of the Currency" intended, we think, to allow the Comptroller to consider as a factor in his decision to grant or refuse approval, the public interest, need and necessity, and, subject to court review, to exercise his discretion in determining such interest, need or necessity.... On the remand of this case, the plaintiff may adduce evidence demonstrating the impermissibility of the Comptroller's approval of a branch bank at Smithfield. Testimony to the contrary will be receivable from the Comptroller. The Court will then find the facts. Thereon, it will judge de novo the validity, in fact and in law, of the Comptroller's final action.

The standards by which the Comptroller's action will be measured are, first, the criteria enumerated in the Banking Act, i2 U.S.C. $\$ 36(c)$ supra, viz: whether the establishment of the branch is "authorized to State Banks" and the location conforms to the restriction of State laws. The capital requirements of the statute have, concededly, been met. If after the court has made its fact findings, it then appears that the decision of the Comptroller is dependent upon an exercise of discretion, the Court cannot substitute its discretion for the Comptroller's. However, it can set aside such a determination if, in the light of the facts found by the Court, it concludes that the Comptroller has abused, exceeded or arbitrarily applied his discretion.

Judge Sobeloff, the dissenting judge in Smithfield, agreed with the majority that there was no requirement of a trial-type hearing but thought that the case should be sent back to the Comptroller for further informal conferençe-type proceedings. He cited Professor Davis to the effect that such conferences are preferable to trials in banking matters, provided that they are fair. ${ }^{20}$

Other cases holding that no formal hearing is required for branch applications are the district court decisions in Continental Bank v. National City Bank, ${ }^{21}$ American Bank \& Trust Co. v. Saxon, ${ }^{22}$ Southern Michigan National Bank v. Saxon. ${ }^{23}$

\section{CONCLUSION}

We in the Comptroller's Office shall of course continue our efforts to provide maximum fairness and efficiency in our administrative procedures. Our aim is to provide a procedure wherein all parties are fully apprised of their opponents' contentions and of all relevant factual material in our files. We are hopeful and confident of being able to continue the evolution of an informal hearing procedure

\footnotetext{
${ }^{19} I d$, at 272 .

${ }^{20} \mathrm{Id}$. at 275 .

${ }^{21} 245$ F. Supp. 684 (N.D. Ohio 1965).

${ }^{22} 248$ F. Supp. 324 (W.D. Mich. I965).

${ }^{28}$ Civil No. 4948 (W.D. Mich., May 2, I966).
} 
which will not only be fair to all parties but will provide a sufficient written record for review by the courts, where appropriate, under the usual standards of administrative law.

As in other areas of bank supervision, the Comptroller's Office has been in the vanguard of progress in the area of hearing procedure. The scouts in the vanguard of the column must expect to take the hardest blows, but they should never be blamed for the length of the trail.

\section{BANKING AGENCIES' SECRECY: A RESPONSE TO MR. BLOOM}

\section{Kenneth Culp Davis}

The preceding article by Mr. Bloom, Chief Counsel to the Comptroller of the Currency, seems to me very encouraging. My purpose has been to persuade the banking agencies to move away from their traditional systems of secret facts, secret law, and secret policy, which they all seemed to me to be following when I was making my inquiries during the spring and summer of 1966 . The Comptroller of the Currency since that time has moved a long way. I am especially pleased with Mr. Bloom's generalization that "most of the criticisms that form the basis of Professor Davis's article appear to have been met."

Although Mr. Bloom's observation that "we are still frankly in a period of development and experimentation" deserves to be read sympathetically, I cannot help but regret the continuing violation of section 3 of the Administrative Procedure Act, which requires publication of procedural rules in the Federal Register. Even if a change in a rule is experimental, the act requires its publication. For instance, the Comptroller says officially in the Comptroller's Guidelines for National Bank Directors that the examiner's report is "confidential." Mr. Bloom now says that "Since July $\mathrm{I} 966$, the report of investigation of the Comptroller's field examiners has been made available to applicants and protestants." To comply with clear legal requirements, as well as to avoid confusion, the new rule should be announced in the Federal Register.

The gains in the Comptroller's Offce are impressive: The system of secret facts has ended during $x$ g66; all facts are now open except to the extent that confidentiality of specific facts is essential. The system of secret law is apparently ending; Mr. Bloom says that "the Comptroller has recently started to write opinions in contested cases summarizing the factual and legal bases for his decision." I think a rule should require systematic statement of findings of fact in all cases. The rule should provide that findings and reasons shall be open to public inspection except when specific information must be confidential. The system of secret policy will gradually end as 
open precedents accumulate. With respect to charter and branch applications, Mr. Bloom says that "the nature of these decisions renders it not only unwise but virtually impossible to spell out these factors in great detail." Yes, that is true, but what now appears "unwise" and "virtually impossible" will gradually become both wise and possible as a body of open case law develops. Policy statements and rules can then boost the movement toward further clarification and can interact with still more case law.

I applaud the Office of the Comptroller for its recent procedural progress, and I hope the other banking agencies will make their own studies and follow in the same general direction. 